\begin{tabular}{c|c|l|l|l}
\hline Volume 1 & Issue 3 & December (2020) & DOI: 10.47540/ijsei.v1i3.81 & Page: $234-238$ \\
\hline
\end{tabular}

\title{
Uninhabitable Home: Portraits of Poverty in Cities
}

\author{
Syahban Nur ${ }^{1}$, Andi Agustang ${ }^{2}$, Arlin Adam ${ }^{3}$ \\ ${ }^{1}$ Universitas Muhammadiyah Makassar, Indonesia \\ ${ }^{2}$ Universitas Negeri Makassar, Indonesia \\ ${ }^{3}$ Universitas Pejuang Republik Indonesia, Indonesia
}

Corresponding Author: Syahban Nur; Email: syahban@unismuh.ac.id

\begin{tabular}{|c|c|}
\hline A R T I C & E I N F O \\
\hline $\begin{array}{l}\text { Keywords } \\
\text { Family; U }\end{array}$ & $\begin{array}{l}\text { Cultural Poverty; Nucl } \\
\text { inhabitable Home. }\end{array}$ \\
\hline Received & : 13 August 2020 \\
\hline Revised & : 09 October 2020 \\
\hline Accepted & : 05 December 2020 \\
\hline
\end{tabular}

\section{ARTICLE INFO}

\begin{abstract}
A B S T R A C T
This research is a mixed study that aims to identify the factors that cause family members to survive in an uninhabitable house. The results of the research data used the direct interview method with a questionnaire to the head of the household regarding information on population, household size, age, gender, ethnicity, religion, employment status, income level, etc. This study uses direct observation, to obtain information about the availability and quality of infrastructure, facilities, and services such as housing conditions, drinking water, supply, roads, drainage systems, and solid waste disposal and management so that data is obtained that two houses do not meet the standard of feasibility. Both in terms of size and design of the house, each house is inhabited by two nuclear families consisting of eight and seven people. Therefore, the subjects of this research are four heads of families who live in RW 5/RT 5 of Pattingalloang Village. The results showed that two factors led to the fact that several nuclear families chose to live in an uninhabitable house in Pattingalloang Village, namely cultural poverty and structural poverty experienced by residents of unfit for habitation.
\end{abstract}

\section{INTRODUCTION}

Housing is one of the basic human needs besides clothing and food. Apart from functioning as a place to rest or shelter from the rain and hot sun, it also functions as a place to foster household life and socialize among individuals in the home and develop themselves. The house can be used as an indicator to measure the social level of the community and the success of development in the housing sector. The existence of the house is not only about quantity but also regarding the quality of the house. The physical condition of the building indicates the quality and quantity of occupied dwellings. Physically strong buildings made of harmless materials ensure the safety of residents not only from the threat of crime but also from the vulnerability of the building itself and the possibility of disease. The physical strength of the building is determined by the selection of building component materials, namely floors, walls, and roofs. Inadequate housing facilities and unsanitary environmental conditions will also affect health.
A place to live is a basic human need, apart from food and clothing. Fulfilling the need for a place to live in the right of every citizen, because it is guaranteed by the 1945 Constitution (as amended) in Article 28 Paragraph 1. This article states that "everyone has the right to live in physical and spiritual prosperity, to have a place to live, and to have a good and good living environment. Healthy and entitled to health services. However, in reality, based on data from the Central Bureau of Statistics (2017-2018), Makassar City is included in an area with a population percentage of $50 \%$ occupying houses with a floor area above $50 \mathrm{M} 2$ with an average member of 4-5 people per household with home comforts. Seen from the floor area of the building, it means that there are residents who do not live in homes that have comfort. The house is the residence of a family consisting of the Core family. The nuclear family is a family or group consisting of fathers, mothers, and children who are not yet adults or have not yet married. Meanwhile, an extended family is a family that 
includes more than one generation from a wider family environment than the father, mother, and children. The more people who live in the house, the more limited the space for separation between one occupant and another. Vice versa, the fewer the number of family members, the wider the distance or space that separates the residents. Space is not made by humans, but humans can feel the existence of that space. Space that is manifested physically, according to Suptandar (1999) is called physical space. It is interesting to examine the existence of space regarding the interactions that occur among the occupants of that space. This is even more so if the room has unique or different characteristics from other rooms.

A housing development that is not facilitated continues following the social needs and economic capacities of each individual which encourages the community to carry out housing and settlement procurement independently. The impact arising from such conditions, especially housing development carried out by low-income people, is the uncontrolled growth and development of settlements that are integrated into a settlement planning following the direction of urban spatial development. Slum areas range from high density, squalid downtown tenements without recognition or legal rights to land scattered on the edge of the city (Kanayochukwu et al., 2019). The world's population is 7.7 billion and more than $50 \%$ of the global population lives in cities and more than $32 \%$ of urban residents live in slums (United National, 2019). The living condition of characterizing a slum are poor public services such as water supply, sanitation, lack of electricity, among others (Noibi, et al., 2020). A slum is defined as the household of a group of individuals living under one roof in urban areas lacking one or more of the following (UN-Habitat, 2003).

Natural permanent durable housing that protects from extreme climatic conditions; enough living space, which means no more than three people sharing the same room; Easy access to clean water at affordable prices; access to proper sanitation in the form of private or public toilets that are shared by a reasonable number of people; and tenure security that prevents forced evictions. In the end, this will cause physical environmental problems and social insecurity. As happened in Pattingalloang Village, Kec. Ujung Tanah Kota
Makassar. There are 2 houses which can be said to be inadequate because the size of this house is very small because the entire building is about $3 \times 5 \mathrm{M}^{2}$ each house must be occupied by two nuclear families consisting of eight and seven people.

Based on the size of the building area and the number of residents in the house, this house can be classified as a house that is not suitable for habitation. This is because if it conforms to the Indonesian National Standard (SNI), this house should have a building area of $72 \mathrm{~m} 2$ or a minimum of $57.6 \mathrm{~m} 2$. This condition causes the physical distance that is formed between family members who live in it to be very narrow, only limited to intimate distance and personal distance. For social distancing, it is not possible to happen because the size of the building on each floor is a maximum of only $3 \times 4$ meters with a size like this which causes the placement of household furniture to create an unsightly view and the house is not healthy because the bed and kitchen and other places are in one room.

The concept of unfit for habitation is limited to this study only because the level of feasibility of a house is relative, depending on which point of view it is. In this study, seen from the concept of distance (proxemic), this house can be categorized as an inadequate house because the size of the house does not match the number of family members living in it. Based on the explanation above, it will be studied more deeply about how the causal factors behind family members can persist in living in an uninhabitable house and cause unsightly views.

\section{MATERIALS AND METHODS}

This type of research was mixed methods in $R W 5$ / RT 5 Pattingalloang-Makassar City. This research instrument was the researcher himself (human instrument) using tools in the form of interview guides, documentation instruments and observation notes, recording devices, and cameras. The data used consisted of quantitative data obtained from the integrated database survey data of Social Service of Makassar City for June 2019 and qualitative data from the results of interviews, observations, and focus group discussions in Pattingalloang Village.

The results of the research data used the direct interview method with a questionnaire to the head of the household regarding the information on 
population, household size, age, gender, ethnicity, religion, employment status, income level, etc. This study used direct observation, to obtain information about the availability and quality of infrastructure, facilities, and services such as housing conditions, drinking water, supply, roads, drainage systems, and solid waste disposal and management so that data was obtained that two houses did not meet the standard of feasibility. Both in terms of size and house design, each house was inhabited by two nuclear families consisting of eight and seven people. Therefore, the subjects of this study were four heads of families living in Pattingalloang Village. Focus The condition of the house was not suitable for habitation and the factors behind the condition of the family who lives in the house are not suitable for habitation (uninhabitable home).

\section{RESULTS AND DISCUSSION}

The subject of the research is the factors behind the family living in an uninhabitable house in 2 families, each of which has 8 and 7 family members living in an unfit house, the space in a house that is unfit for habitation has a very small size and is not suitable. Fixed-featured space or nonverbal communication in the use of space which consists of certain physical elements that are permanent or cannot be moved in this uninhabitable house, only measuring no more than $2.5 \mathrm{~m} \mathrm{x} 2 \mathrm{~m}$ for each space.

The results of in-depth interviews with informants are very diverse, where information obtained from the main informant 1 states that living in a house that is not suitable for habitation because they cannot build a decent house, an uncertain income as a construction worker can only meet daily needs. The main informant 2 since after marriage he only relies on his parents and government assistance. The main informant 3 lives in a house that is unfit for habitation because he does not have sufficient savings and has to pay off family debts and there are family members who always gamble every day. Main informant 4 chose to live in an uninhabitable house because he had not yet got a decent job, so he could only afford to spend his life on his wife's parents and only expected help from the government.

Living and surviving in an uninhabitable house is a solution for informants to be able to survive in a metropolitan city. Choosing to live at home is not suitable for habitation as was done by the second informant because of a sense of laziness and always expecting help from family or other people. It is different from the main informant 5 who lives in an unfit for habitation because the educational background of only elementary school graduates makes it difficult for the informant to find decent work.

There are various reasons for choosing to live in a house that is not suitable for habitation, even though sometimes they feel uncomfortable living in a very narrow house. Where in the very narrow house there are two nuclear families, causing a feeling of discomfort between the two nuclear families. The things that affect the existence of houses that are no longer suitable for habitation in Pattilanggoang are cultural poverty and structural poverty.

Generally, the house is one of the primary needs of every human being besides the need for food and shelter. The house generally functions as a place to live and live, even the house is made as beautiful and comfortable as possible for the residents of the house. but sometimes many people think and assess the house as a measure of conditions and circumstances, especially the economy of a family that lives in it. Meaning that the house is one of the benchmarks to find out how someone's life is. There are many reasons why someone does not have an uninhabitable house and is willing to stay for a long time.

In the aspect of cultural poverty, it can be seen that the main factor that causes the subject to unfit for habitation is cultural poverty, where culture is the cause of cultural poverty, namely in the form of values, culturally developed traditions, and a view of life that develops among them. There are patterns of behavior and attitudes that are shown by the poor as the most appropriate way to survive a life of deprivation. This way of life then becomes the basis for the formation of the culture of poverty they have. Family members do not have permanent jobs, the head of the family is a construction worker where the wages from their work are only enough to make a living from day to day, no more than that. Besides, some informants are caught in debt as experienced by the third informant, namely lifelong debt bondage that will ensnare family members even though the wages of construction workers can increase. From this picture, cultural poverty is a 
form of poverty that is caused by custom, culture, or the nature of family members that makes them poor.

This habit continues, resulting in a continuous process of impoverishment in which as long as a culture of poverty exists in the family, poverty will not move from their lives. Views of life, values that apply in society encourage the realization of this cultural poverty. This explanation is raised from the perspective of conservative circles where people become poor because of their own cultural traps which are then passed on from generation to generation. Another case is the feeling of laziness and dependency with family members which causes poverty experienced by family members as did the second informant who felt lazy and at home to the conditions he was experiencing. Family members who are in the family are trapped in the habits of living social values in the family where they are or they are. Lazy character, life orientation based solely on pragmatic daily needs or not forwardlooking, indulgence towards the environment due to depending on the head of the family who is in the house so that he feels no need to work hard because indeed a source of livelihood can be easily obtained; are some of the factors that then shape culture and then trap them in poor living conditions (Darwin, 2005).

Members of this family class assume that poverty is caused by weak and inferior personal characteristics. The government has also contributed to the proliferation of cultural poverty where socio-cultural poverty was created by the government when the 1997-1999 crisis occurred (Sukamdi, 2003) as experienced by the second informant. The government created a social safety net program (Social Security Net) whose original purpose was to help poor people. The PKH program is provided to reduce poverty, improve the quality of human resources, and change behavior that does not support the improvement of the welfare of the poor. The program aims to meet the basic needs of a decent life as a consequence of reduced income for the poor due to illness, loss of work (retirement), and no old age security for poor elderly people in Pattingalloang, the Family Hope Program (PKH) for poor families with the main objective namely reducing the poverty rate. This program is provided in the form of cash transfers that can help recipients (poor families) to improve their lives (consumption and micro-enterprises) (Kharisma, D., 2008).
In addition to poor families who live in unfit for habitation, PKH is also intended for other components such as the elderly, pregnant women, schoolchildren, and severe disabilities. All this is done by the government to reduce nutritional problems in infants and toddlers through integrated programs in the health sector (Aries, M., et al 2012). PKH touches all levels of society in preparing and improving the quality of life of the next generation so that they can get out of the poverty chain (Kharisma, D., 2008). The government program was designed to reduce poverty levels, but it turned out that this assistance made them (residents of uninhabitable houses) dependent. The assistance provided by the government, which was originally intended to help the population overcome poverty, actually made some aid recipients lazy and dependent.

His income is not enough to meet his daily needs, so it is difficult to buy milk for the baby. The informant had worked in a food stall located far from his residence. So that to save on transportation costs, informants must be willing to walk to the workplace If we examine the information from the informants that living in poverty is something they have to accept and are familiar with, then living in poverty is considered normal, as part of the dynamics of life that they cannot avoid. Surrender and acceptance is a way out of the crisis. so that there is a need for an increase in program activities, outreach, and policy-making targeting urban slum residents (Wamukoyo, et al., 2020)

In the aspect of structural poverty by living in an area that is not feasible and having a family that is unable to make the education of family members inadequate, people with inadequate tertiary degrees, as experienced by the fourth informant who is only a graduate of primary school level education $(S D)$. The fourth informant has almost done all kinds of work, the informant has worked as odd jobs, pedicab drivers, and construction workers. Everything has been done for the survival of his family. His educational background only up to elementary school level made it difficult for the fourth informant to find a decent job. The low level of education of informants means that informants cannot have a more decent job as stated in the type of work of the informant. The quality of the workforce can be seen from the level of education 
because the education a person has will affect his work productivity (Junaidi, M, et al 2017).

His income is not enough to meet his daily needs, so it is difficult to buy milk for the baby. The informant had worked in a food stall located far from his residence. So that to save on transportation costs, informants must be willing to walk to the workplace and must endure the embarrassment of choosing to live in the house of their in-laws which are no longer suitable for habitation so that their families have shelter. Owning a house to your liking is very beneficial for every family (Douglass, 1938) but when the head of the family is unable to make it happen, living in a house that is far from feasible is something that must be accepted.

\section{ConClusion}

There is an underlying cause so that there are several nuclear families who choose to live in an uninhabitable home in Pattingalloang Village. There are two reasons, namely cultural poverty and structural poverty experienced by residents of unfit for habitation.

\section{REFERENCES}

Aries, M., Hardinsyah, H., \& Tuhiman, H. (2012).

Determinan Gizi Kurang dan Stunting Anak Umur 0 - 36 Bulan Berdasarkan Data

Program Keluarga Harapan (Pkh) 2007.

Jurnal Gizi Dan Pangan, 7(1), 20-27.

https://doi.org/10.25182/jgp.2012.7.1.20-27.

Badan Pusat Statistik (2018). Indikator

Kesejahtaraan Rakyat Kota Makassar Tahun 2018. Makassar: Badan Pusat Statistika'.

Darwin, Muhadjir. 2005. "Memanusiakan Rakyat.

Penanggulangan Kemiskinan Sebagai Arus

Utama Pembangunan". Benang Merah:

Yogyakarta.

Douglass, Rizpah Anna.1938. EC1179 The Livable

Home. Historical Materials from University

of Nebraska-Lincoln Extension. 2471.

Fathoni, Abdurrahmat. 2006. Metodologi Penelitian

\& Teknik Penyusunan Skripsi. Jakarta:

PT.Rineka Cipta.

Junaidi, M. S., Setiawan, B. M., \& Prastiwi, W. D.

(2017). The Satisfaction Comparison of

Bantuan Pangan Non Tunai Recipients and

Rastra Recipients In Cakung District, East

Jakarta. Jurnal Ilmiah Econosains, 15(2),

274-288. http://doi.org/10.21009/econosains.0152.08.

Kanayochukwu,E.C. and Dogo, B. (2019) Profiling

the Characteristics of Karu Slum, Nasarawa

State, Nigeria. Journal of Service Science

and Management, 12, 605-619.

https://doi.org/10.4236/jssm.2019.125041

Kharisma, D. D. (2008). Case study of PK H (CCT

Indonesia) in Sumba Barat and Kediri. Asian

Social Protection in Comparative

Perspective, Singapore, 7-9.

Noibi, T. O., Murrieta, R. L. M., \& Pandey,

Digvijay. (2020). The Resurgence of

Informal Settlements in Cuidad Juarez:

Estrella Sol del Poniente, Causes and

Conditions. Indonesian Journal of Sosial and

Enviromental Issues (IJSEI).

https://ojs.literacyinstitute.org/index.php/ijsei /article/view/26

Octavianti, Meria. 2016. Komunikasi Nonverbal Proksemik Di Rumah Tidak Layak Huni.

Volume 4, No. 1, Page 10-27.

Sukamdi dan Setiadi. 2003. "State-Created Socio-

Cultural Poverty: Lesson from Some Micro

Studies" dalam The Indonesian Crisis, A

Human Development Perspective ed Aris

Ananta. Institute of Southeast Asian Studies: Singapore

Suptandar, J. P. (1999). Desain interior: pengantar merencana interior. untuk mahasiswa desain dan arsitektur. Jakarta: Djambatan.

Wamukoya, M., Kadengye, D.T., Iddi, S., \& Chikozho, C. (2020) The Nairobi Urban Health and Demographic Surveillance of slum dwellers, 2002-2019: Value, processes, and challenges. Global Epidemiology 2.

United Nations (2019) World Population Prospects 2019 Highlights. Department of Economic and Social Affairs Population Division, UN, New York. 